\title{
PEMULANGAN "WARGA NEGARA INDONESIA EKS ISLAMIC STATE OF IRAQ AND SYRIA (ISIS)" DALAM PERSPEKTIF HAM
}

\author{
Lina Maryani, Tabah Sulistyo \\ Fakultas Hukum Universitas Indonesia, Jakarta \\ lina.maryani@ui.ac.id
}

\begin{abstract}
Abstrak
Penelitian ini bertujuan untuk menganalisis fenomena ISIS dan pemulangan "Warga Negara Indonesia Eks ISIS" dari sudut pandang ketatanegaraan secara umum dan HAM guna memberikan pertimbangan dalam pengambilan keputusan tentang nasib Warga Negara Indonesia Eks ISIS. Berangkat dari permasalahan berakhirnya ISIS membawa Warga Negara Indonesia Eks ISIS menjadi terlantar. Radikalisme sebagai bentuk ideologi ekstrim yang disematkan pada organisasi ISIS dan kental dengan kekerasan serta anti terhadap negara membuat pemerintah enggan untuk memulangkan Warga Negara Indonesia Eks ISIS. Pemerintah Indonesia sampai sekarang belum memutuskan nasib "Warga Negara Indonesia Eks ISIS yang masih berada Suriah dan sekitarnya". Metode penelitian menggunakan pendekatan yuridis normatif. Penelitian ini menyimpulkan bahwa dari segi pemenuhan atas syarat deklarasi Montevideo ISIS bukan negara. Dalam perspektif HAM, ISIS lebih tepat disebut dijuluki terorisme yang melakukan pelanggaran HAM berat dan dapat dikategorikan sebagai penjahat perang sebagaimana Hukum Humaniter Internasional. Langkah pemulangan Warga Negara Indonesia Eks ISIS adalah bentuk tanggungjawab Indonesia dalam menjaga ketertiban dunia dengan menindak warga negaranya yang melakukan kejahatan transnasional.
\end{abstract}

Kata kunci: Hak Asasi Manusia; Pemulangan; WNI Eks ISIS

\section{REPATRIATION OF EX ISLAMIC STATE OF IRAQ AND SYRIA (ISIS) INDONESIAN CITIZENS FROM A HUMAN RIGHTS PERSPECTIVE}

\begin{abstract}
The aim of this research is to analyze the phenomenon of ISIS and and the repatriation of Ex-ISIS Indonesian Citizens" from a general constitutional and human rights perspective to give consideration in making decisions about the fate of former ISIS Indonesian citizens. Starting from the problem of ending ISIS, Indonesian citizens who are ex-ISIS become displaced. Radicalism as a form of extreme ideology embedded in the ISIS organization and thick with violence and anti-state makes the government reluctant to repatriate Indonesian citizens who are ex-ISIS. Until now, the Indonesian government has not decided the fate of "Indonesian citizens who are ex-ISIS who are still in Syria and its surroundings". The research method uses a normative juridical approach. This research concludes that in terms of fulfilling the requirements of the Montevideo declaration, ISIS is not a State. From a human rights perspective, ISIS is more accurately called terrorism which commits gross human rights violations and can be categorized as war criminals according to International Humanitarian Law. The step of repatriating ex-ISIS Indonesian citizens is a form of Indonesia's responsibility in maintaining world order by taking action against its citizens who commit transnational crimes.
\end{abstract}

Keywords: Human Rights; Repatriation; Indonesian Citizens Ex ISIS 


\section{PENDAHULUAN}

\section{A. Latar Belakang}

"Islamic State of Iraq and Syria (ISIS)" telah menjadi fenomena Internasional. Bermula dari organisasi yang bersifat regional, ISIS mengembangkan sayapnya menjadi organisasi yang berkembang dengan pesat dibeberapa negara. ISIS mengembangkan sayapnya melalui mediamedia tekhnologi dengan menggunakan isu agama sebagai pemantik. Radikalisme ISIS dengan memanfaatkan isu SARA dan janji surga semakin menyebar dan menimbulkan kebencian pada pengikutnya. Militansi pengikut ISIS sangat mengerikan, mereka mengorbankan materi, hingga mengorbankan jiwa dan raga. Tak jarang keluarga baik istri maupun anak mereka dilibatkan dalam perjuangan mereka. Banyaknya warga negara yang meninggalkan negaranya demi bergabung ke ISIS adalah suatu bukti militansi mereka. Selain itu banyak aksi bom bunuh diri dibeberapa negara yang diklaim oleh ISIS.

Radikalisme sebagai bentuk ideologi ekstrim yang disematkan pada organisasi ISIS, membuat negara-negara asal dari "penduduk" ISIS ini enggan untuk mengambil kembali warga negaranya. Hal ini di karenakan ISIS sangat kental dengan kekerasan dan anti terhadap negara. Aksi kekerasan yang dilakukan ISIS merupakan pelanggaran HAM dan bertentangan dengan prinsip hukum humaniter internasional.

Berakhirnya nasib ISIS membawa imbas terhadap pendukung gerakan ISIS. Kombatan dan non kombatan baik laki-laki, perempuan maupun anak-anak dalam kondisi terdampar karena induknya telah ditumpas. ISIS sebagai organisasi dengan kombatan dan simpatisan dari berbagai negara, menempatkan mereka dalam keadaan terlantar. Pemerintah hendak melakukan screening dan pemetaan atas warga Indonesia yang terlibat ISIS, sebagai cara-cara antisipatif agar kemungkinan resiko jika diterima, eks ISIS dapat menjadi warga negara yang baik. Atau pun menimbang untuk tidak lagi menerima mereka di Indonesia karena potensi destruktifnya.

Setelah ISIS diklaim telah ditumpas, sebanyak 689 warga negara Indonesia (WNI) dinyatakan masih berada di Suriah dan sekitarnya, hampir $70 \%$ adalah perempuan dan anak dan sisanya adalah laki-laki. Pemerintah sampai dengan sekarang belum memutuskan nasib eks kombatan dan warga negara Indonesia tersebut. Nasib WNI Eks ISIS harus diputuskan oleh pemerintah. Pemerintah harus memutuskan tindakan atas pelanggaran HAM yang dilakukan oleh kombatan ISIS serta status kewarganegaraan WNI Eks ISIS.

Hak atas kewarganegaraan telah diakui dalam Deklarasi Universal Hak Asasi Manusia. Setiap orang berhak atas kewarganegaraan, tidak seorang pun 
boleh secara sewenang-wenang dirampas kewarganegaraannya, atau ditolak hak untuk mengubah kewarganegaraannya. Pemerintah mempunyai kewajiban untuk melindungi dan menjamin hak kewarganegaraan WNI. Perlindungan terhadap HAM merupakan bagian esensial dari negara hukum. Indonesia yang masih belajar tentang HAM dan transisinya, memerlukan proses afirmasi yang berbeda dengan negara-negara yang sudah lebih awal mempraktikkan HAM. Suatu perjalanan universalitas hukum dari relativitas yang semakin menghilang ditelan perkembangan HAM secara internasional. Perlindungan atas HAM WNI Eks ISIS tentunya diimbangi juga dengan penegakkan atas pelanggaran HAM yang dilakukan oleh WNI Eks ISIS.

Penelitian sebelumnya yang mengkaji tentang pemulangan WNI pernah diteliti salah satunya oleh Sumawiharja (2020) pada penelitiannya tersebut lebih fokus mengkaji tentang bagaimana kebijakan pemulangan WNI pendukung ISIS di Suriah. Penelitian tersebut menggunakan model analisis pendekatan "stakeholders analysis". Model ini digunakan untuk mencari titik temu dari sekian banyak konflik kepentingan yang muncul dari akibat kebijakan yang timbul tentang penerimaan kembali WNI pendukung ISIS kembali ke Indonesia. ${ }^{1}$ Selanjutnya penelitian Hakim (2020) mengangkat permasalahan yang sedikit berbeda dengan penelitian sebelumnya. Penelitian ini mengangkat permasalahan bagaimana pro dan kontra pemulangan WNI Eks ISIS. Analisis kasus dalam penelitian ini menggunakan konsep maslahah untuk mendapatkan rumusan kebijakan yang seharusnya diterapkan pemerintah dalam mengatasi problem pemulangan WNI Eks ISIS. ${ }^{2}$ Penelitian selanjutnya dilakukan oleh Lovelycia (2020) juga mengangkat permasalahan yang sedikit berbeda dengan penelitian sebelumnya, penelitian lebih fokus mengkaji tentang penolakan pemerintah atas pemulangan WNI eks ISIS ditinjau dari hukum positif Indonesia. ${ }^{3}$

Penelitian ini berbeda dengan penelitian-penelitian sebelumnya, penelitian ini mengkaji lebih komprehensif tentang fenomena ISIS, Pelanggaran HAM yang dilakukan oleh ISIS ditinjau dari hukum humaniter, hak kewarganegaan WNI Eks ISIS, dan dilema pemulangan WNI Eks ISIS. Tujuan dari penelitian ini adalah menganalisa fenomena ISIS dan

\footnotetext{
${ }^{1}$ Farhan Arif Sumawiharja and Adis Imam Ismunandar, "Analisa Kebijakan Penerimaan WNI Mantan Simpatisan ISIS Di Suriah (Policy Analysis of Re-Acceptance Indonesia Citizenship Former ISIS in Suriah)", Jurnal Keamanan Nasional, VI.1 (2020), 107 <https://elshinta.com/news/160416/2018/11/08/menhan-sebut-700-wni-gabung-isis-di-suriah-dan-.

2 Abdurrahman Hakim and Iffatin Nur, 'Indonesia Eks ISIS', 9.1 (2020), 81-98.

3 Keivelyn Lovelycia, "Indonesia Atas Kepulangan Warga Negara Indonesia Eks Isis (Islamic State Of Iraq And Syria) Ditinjau Dari Hukum Positif Indonesia", Jurnal Hukum Adigama, 3.2 (2020), 1213-38.
} 
pemulangan Warga Negara Indonesia Eks ISIS dari dalam perspektif ketatanegaraan secara umum dan sudut pandang HAM guna memberikan pertimbangan dalam pengambilan keputusan tentang nasib Warga Negara Indonesia Eks ISIS.

\section{B. Permasalahan}

Rumuan masalah dalam penelitian ini, yaitu:

1. Bagaimanakah kedudukan ISIS dalam konstelasi internasional?

2. Bagaimanakah perspektif HAM atas fenomena ISIS?

3. Bagaimanakah dilema dalam pemulangan warga eks ISIS ke negara Indonesia?

\section{Metode Penelitian}

Penelitian ini menggunakan pendekatan yuridis normatif. ${ }^{4}$ Dengan tipelogi penelitian yang deskriptif yang akan menggambarkan suatu masalah dalam peristiwa hukum secara terperinci dan menganalisisnya dengan menggunakan peraturan perundang-undangan. Penelitian ini bersumber dari data sekunder dengan melakukan penelusuran literatur atau studi kepustakaan terhadap peraturan perundang-undangan, buku, jurnal, dan data-data sekunder lain yang berkaitan dengan topik penelitian. Metode analisis data yang digunakan adalah metode kualitatif di mana analisis dan pengolahan data berdasarkan pemahaman terhadap data atau informasi yang diperoleh yang kemudian dinarasikan untuk memperoleh simpulan penelitian.

\section{HASIL DAN PEMBAHASAN}

\section{A. Kedudukan ISIS dalam Konstelasi Internasional.}

\section{Ketatanegaraan ISIS}

ISIS dalam strukturnya mempunyai bentuk layaknya negara dengan kelengkapan lembaga-lembaga sebagai berikut:

a. Kewenangan peradilan: menurut sistemnya meliputi: 1) Pengadilan Islam. 2) Otoritas Yudisial: ini berhubungan dengan semua masalah yudisial.

b. Otoritas Legislatif: untuk ISIS ini termasuk: Dewan Syura (Konsultatif): dewan ini terdiri dari 9-11 anggota, semuanya dipilih oleh khalifah. Tugas utama Dewan adalah mengawasi urusan negara.

c. Kewenangan eksekutif: bagian eksekutif meliputi pertahanan, militer, dan hubungan masyarakat: 1) Militer: Dewan Militer: terdiri dari tiga anggota yang ditunjuk oleh khalifah. Dewan ini bertanggung jawab untuk merencanakan dan mengawasi aksi dan operasi militer. 2) Keamanan: Dewan Pertahanan, Keamanan dan Intelijen: bertanggung jawab atas keamanan khalifah, dan yang paling penting melaksanakan perintah,

${ }^{4}$ Sri Mamuji, Soerjono Soekanto, Penelitian Hukum Normatif(Jakarta: Raja Grafindo Persada, 
kampanye, keputusan peradilan, dan tujuan intelijen. 3) Humas untuk menyebarkan pesan khalifah. ${ }^{5}$

Dari awal berdirinya sebagai Al-Qaeda in Iraq, ISIS selalu mencoba menghidupkan sistem khalifah, sebetulnya hal tersebut merupakan cita-cita yang sama antara Al Qaeda dan ISIS sendiri. Namun alih-alih untuk membentuk suatu negara, ISIS sendiri lebih menempatkan diri sebagai gerakan militer daripada memakmurkan atau dalam rangka mengatur suatu bangsa. Permasalahan inti dari perdebatan harus berbentuk ke-khalifahan atau tidak seharusnya lebih digali dalam ketatanegaraan. Sebagai tanggung jawab negarawan muslim untuk bisa mengimbangi doktrin ISIS terkait pemaksaan bentuk negara dalam ketatanegaraan. Komunitas muslim harus mulai memikirkan cara untuk menghadang pendapat-pendapat dari kaum ekstrimis yang memaksakan bentuk khalifah untuk mengatasi masalah ini. Melakukan kajian yang konstruktif tentang hubungan antara Islam dan negara. Otoritas Yudisial ISIS Dipimpin oleh Abu Mohammad Al-Ani, otoritas menangani semua masalah peradilan serta menyebarkan pesan negara Islam melalui perekrutan dan pemberitaan. ${ }^{6}$

Peran khalifah dalam pemilihan pimpinan judikatif sangat dominan, sehingga dari konsep independensi jelas intervensi caliph sangat dominan. Dengan penggunaaan hukum Islam sebagai dasar judicative nya, kecenderungan yang dilakukan oleh ISIS sendiri adalah terjemahan sebagaimana Fiqih Al Dima, di mana pemaknaan hukum Islam nya juga terpengaruh atas kebenaran atas sudut pandang fiqh mereka yang disusun oleh Muhajir dalam yurisprudensi darah. Keadilan yang dilakukan oleh ISIS sendiri distortif dengan cara ISIS memandang dunia, bahwa tindakan ISIS merasa paling benar dari sudut pandang mereka.

\section{Pemenuhan Syarat Negara Oleh ISIS}

Negara menurut Deklarasi Montevideo harus memenuhi beberapa unsur atau syarat utama,yaitu: a. penduduk tetap; b. wilayah tertentu; c. pemerintah berdaulat; dan d. kapasitas berhubungan dengan negara lain. Dalam praktik ketatanegaraan dunia internasional untuk unsur pemerintah berdaulat dan kepasitas berhubungan dengan negara lain lebih dikenal dengan syarat kedaulatan. Pemenuhan syarat negara oleh ISIS diuraikan sebagai berikut:

${ }^{5}$ Luna Shamieh and Szenes Zoltán, "The Rise of Islamic State of Iraq and Syria (ISIS) Islam and Politics", Aarms, 14.4 (2015), hal. 363-378.

${ }^{6}$ J Neriah, "The Structure of the Islamic State ISIS", Jerusalem Center for Public Affairs, 2014 https://jcpa.org/structure-of-the-islamic-state/, diakses 13 February 2021. 
a. Pada 2014 diperkirakan delapan juta orang tinggal di tempat yang mengklaim dirinya sebagai negara Islam (ISIS). ${ }^{7}$ Persebaran dari "Penduduk" ISIS sendiri belum tentu ada di Irak atau Suriah. Karena mobilitasnya, penduduk ISIS akan kembali ke negaranya untuk menyebarkan ajaran ataupun teror. Dengan fakta yang demikian, ISIS mempunyai anggota dengan loyalitas yang tinggi, dan menggunakan baiat untuk masuk ke negara "ISIS". Beberapa penduduk di Suriah atau pun di Irak yang bergabung dalam ISIS merupakan penduduk asli Irak dan Suriah, dan berdomisili disana.

Dengan demikian dapat disimpulkan syarat penduduk kurang lebih dapat diklaim sebagai terpenuhi, namun tidak berarti berdomisili dalam kaitan area. Diksi penduduk sendiri belum tentu tepat, diksi yang mungkin lebih tepat adalah afiliasi. Hal tersebut sebagai akibat mayoritas pendukung ISIS memiliki kewarganegaraan lain juga sesuai dengan lokasi dan jenis memperoleh kewarganegaraanya dengan apa, apakah ius soli atau ius sanguinis.

b. Wilayah ISIS sendiri sangat terkait dengan perubahan nama dan julukan dari nama Islamic State. Wilayah yang menjadi klaim dari ISIS sendiri masih terdapat negara-negara yang berdaulat dan mempunyai penduduk dan pemerintahan sendiri. Dari sisi wilayah, kejelasan wilayah dari ISIS sendiri masih berupa klaim dan hal ini sangat terkait dengan syarat selanjutnya sebagai syarat suatu negara. Tidak dapat disangkal fakta bahwa ISIS telah mampu mengendalikan sebagian besar wilayah Irak dan Suriah. Tetapi sampai saat ini tidak ada batas tetap. Penaklukan teritorial belum diakui oleh salah satu negara yang terlibat. Irak dan Suriah secara bersamaan mempertahankan bahwa zona yang bersangkutan masih merupakan bagian integral dari wilayah nasional masing-masing. Hanya garis depan yang dapat diidentifikasi, yang berubah sesuai dengan keuntungan atau kerugian yang ditimbulkan oleh pertempuran militer yang sedang berlangsung. Situasi yang cair dan tidak jelas seperti itu tidak memungkinkan karakterisasi tanah yang secara faktual dikendalikan oleh ISIS pada saat tertentu sebagai wilayah 'nasional'. Suatu entitas di atas roda, tergantung pada keberhasilan atau kegagalan militer, tidak memiliki persyaratan penting stabilitas dan kontinuitas. ${ }^{8}$

Dari hal ini dapat disimpulkan klaim negara Iraq dan Suriah atas negaranya sendiri masih ada, sehingga teritori ISIS ini masih tergantung pada keberhasilan militer untuk menguasai wilayah, dan klaim atas wilayah tertentu oleh ISIS juga tidak serta merta menunjukkan ISIS mempunyai teritori. Adapun Islamic State menurut ISIS meliputi Andalus di barat

\footnotetext{
https://www.youtube.com/watch? $v=1$ HzMucorCwo

Leadership Is Organized', 2014

8 Christian Tomuschat, "The Status of the "Islamic State" under International Law', Die Friedens-Warte, 90 (2015), hal. 229 , https://www.jstor.org/journal/friedenswarte?.
} 
(Spanyol) dan membentang dari Afrika Utara - Maghreb - (dan seluruh Afrika Barat termasuk Nigeria) melalui Libya dan Mesir (dianggap sebagai satu unit geografis - Ard Al-Kinana), termasuk apa yang disebut dalam terminologi negara Islam, Ard el Habasha (dari Kamerun di barat, Afrika Tengah, negaranegara danau Victoria, Ethiopia dan Somalia), Hijaz (Arab Saudi, negaranegara Teluk), Yaman hingga Khurasan di timur - didefinisikan sebagai Republik Muslim Asia dimulai dengan Azerbaijan dan termasuk Pakistan dan bagian barat daya Cina, tanah Muslim asal Turki, Uyghur. Negara Islam termasuk juga Iran dan Turki (bernama Anadol) secara keseluruhan dan sebagian Eropa (terutama Balkan, kurang lebih sesuai dengan perbatasan Kekaisaran Ottoman dengan wilayah Austro-Hongaria). ${ }^{9}$

c. Kedaulatan negara ISIS sangat terkait dengan pengakuan dari negara lain secara terbuka maupun diam-diam. Indikatornya bisa berasal dari pemerintah resmi yang menyatakan dukungan ataupun menjalin kerjasama dengan ISIS. Dari data yang di dapat, belum ada satupun negara (pemerintah resmi) yang menyatakan keberadaan ISIS sebagai negara yang berdaulat dan dapat dikategorikan sebagai negara utuh sebagaimana deklarasi Montevideo.

Dari ketiga syarat utama suatu negara dapat dikatakan bahwa ISIS bukanlah suatu negara dan tidak memenuhi syarat utama dikatakan suatu negara, yaitu mempunyai penduduk, wilayah tertentu, dan pemerintah yang berdaulat, dan pengakuan serta kapasitas berhubungan dengan negara lain.

Mengacu kepada ilmu negara dan ketatanegaraan, serta dikaitkan dengan teori syarat suatu negara, masih sumir untuk mengatakan ISIS sebagai "negara". Klaim lebih lanjut perlu di kaji dari konsekuensi atas bubarnya ISIS terhadap hak-hak yang muncul secara internasional, dikarenakan simpatisan dari ISIS sendiri berasal dari kurang lebih 80 negara di luar Iraq dan Suriah. Secara konkrit bisa ditarik kesimpulan ISIS tidak memenuhi syarat sebagai negara.

\section{B. Perspektif HAM atas Fenomena ISIS \\ 1. Ideologi ISIS dan Kebebasan Beragama}

ISIS merupakan fenomena internasional, menyebar dengan sangat cepat dan "viral" dengan memanfaatkan media tekhnologi sebagai sarana. ISIS muncul sebagai latarbelakang perkembangan ideologi, dengan mengatasnamakan Islam sebagai ideologi dan klaim bentuk organisasi Negara. Pemurnian dari unsur bid'ah yang menjadi dasar kebrutalan ISIS dan juga menjadi ideologi ISIS. ISIS ingin membuat suatu negara Islam trans-negara dengan segala kemungkinan baru. Dengan model khalifah

\footnotetext{
9 Neriah.
} 
mendasarkan syariah sebagai dasar hukum dan dimana sebagai contoh potong tangan untuk pencuri.

ISIS tidak hanya menyasar kaum non muslim, tapi pada kenyataanya ia menyerang semua orang yang tidak sesuai dengan strateginya termasuk muslim sendiri (sunni). Efek dari penggunaan nama IS (Islamic State) sendiri memberikan stigma buruk kepada Islam. Meskipun pada perkembangannya tak lagi ideologi yang digunakan ini terbatas pada Islam, bahkan diterima oleh pemuda-pemuda diluar agama Islam. ISIS adalah kelompok ekstremis Sunni yang berbasis di Irak dan Suriah dan mantan afiliasi Al-Qa'ida yang menganut ideologi jihadis global. Negara Islam mengikuti interpretasi ekstrim Islam yang anti-barat, mempromosikan kekerasan sektarian dan menargetkan mereka yang tidak setuju dengan interpretasinya sebagai kafir dan murtad. ${ }^{10}$

Dalam kontekstualisasi kebebasan beragama jelas bahwa sebenarnya ideologi yang tepat untuk menggambarkan ISIS adalah menggunakan kata terorism atau atrocicism. Menggunakan kata radikalisme masih mengandung diksi netral sehingga perlu disadari penggunaan kata yang tepat, sedangkan barier dari kebebasan beragama adalah sebagaimana diatur dalam Pasal 18 ayat (3) Kovenan Internasional tentang Hak Sipil dan Politik.

a. Pelanggaran HAM oleh ISIS

Kejadian Pelanggaran HAM oleh ISIS di Indonesia setidaknya terjadi selama tiga kali. Kasus pertama terjadi pada bulan Januari 2016 di Sarinah Jakarta Pusat. Aksi bom bunuh diri di Sarinah Jakarta Pusat ini mengakibatkan 7 orang meninggal dan 19 orang luka-luka. Korban yang meninggal terdiri dari 2 masyarakat dan 5 diantaranya adalah pelaku bom bunuh diri. ${ }^{11}$ Kasus kedua terjadi tahun 2017, terjadi pengeboman di stasiun bus transjakarta yang setidaknya mengakibatkan 5 orang meninggal dan 11 orang luka-luka. Korban yang meninggal dunia terdiri dari 3 anggota Polri dan 2 terduga pelaku. ${ }^{12}$

Kasus ketiga terjadi pada bulan Mei 2018. Pada tahun 2018 bom Gereja Surabaya adalah serangkaian serangan teroris yang terjadi pada 13 Mei 2018 di tiga gereja di Surabaya, yaitu: Gereja Katolik Santa Maria Tak Bercela (SMTB) di Gereja Santa Maria Tak Bercela, di Jalan Ngagel Madya, Gereja Pantekosta Pusat Surabaya (GPPS) Surabaya di Jalan Arjuno, dan

\footnotetext{
10 The Islamic State: How Its Leadership Is Organized'., https://www.nationalsecurity.gov.au/Listedterroristorganisations/Pages/IslamicState.aspx.

${ }^{11}$ EPA, 'Polri: Korban Ledakan Di Sarinah 7 Tewas, 5 Adalah Pelaku', 2016, https://www.bbc.com/indonesia/berita_indonesia/2016/01/160114_indonesia_jumlah_korban, diakses 21 Februari 2021.

${ }_{12}$ Agung DH, "Kesaksian Penumpang Bus Trans Jakarta Saat Bom Meledak", 2017, https://tirto.id/cpnc https://tirto.id/cpnc, - 25 Mei 2017, diakses 21 Februari 2021.
} 
Gereja Kristen Indonesia, GKI) di Jalan Diponegoro. Lebih dalam terkait ideologi terorisme yang dianut oleh ISIS ini akan terlihat dampaknya dalam kasus-kasus terorisme yang dilakukan atau di klaim sebagai tindakan ISIS.

\section{Dilema dalam pemulangan warga eks ISIS ke negara Indonesia}

Setelah ISIS ditumpas, permasalahan menjadi lebih kompleks jika terkait dengan "mass crime". Lingkup pelanggaran HAM sangat luas dan pelakunya juga sangat banyak. Jika harus dilakukan hukuman maka akan mengacu pada kejahatan individu. Setelah ISIS dikalahkan, komunitas internasional akan menyadari sekali lagi betapa sulitnya menangani kejahatan massal. Berbagai pelanggaran hak asasi manusia yang paling mendasar, yang merupakan kejahatan perang dan kejahatan terhadap kemanusiaan, yang dilakukan oleh para pejuang ISIS melebihi dimensi yang bisa dibayangkan, dan jumlah pelaku yang terlibat juga telah mencapai rekor negatif yang tinggi. Jika di masa depan seluruh divisi ISIS harus ditawan, aturan hukum akan tetap mengharuskan para pejuang ISIS yang bertanggung jawab diadili secara individual, sesuai dengan kesalahan pribadi mereka. ${ }^{13}$

Menurut Abdul Mu'ti, ada 3 kategori WNI yang bergabung dalam kelompok ISIS ${ }^{14}$ Pertama, mereka yang berangkat karena alasan ideologis. Kedua, mereka yang bergabung karena alasan pragmatis, yaitu diimingimingi insentif besar, biasanya tidak memiliki ideologi yang kuat; dan Ketiga, mereka yang datang karena ikut-ikutan bahkan tertipu anggota keluarga dan teman. Jika dikaitkan dengan tipologi pendukung ISIS ini, tipe pertama yang mempunyai ideologi terorisme dan atrocitism. Sedangkan tipe kedua dan ketiga perlu di-screening lebih lanjut untuk mengetahui perannya dalam kejahatan massal oleh ISIS. Screening terhadap peran dari masing-masing WNI diperlukan sebagai bentuk persamaan di depan hukum dan penerapan asas praduga tak bersalah.

Dalam fenomena ISIS untuk membedakan combatant dan non combatant memerlukan kejelian, karena tidak jarang seorang anak kecil telah menjadi kombatan bahkan ada yang menjadi kombatan di usia dibawah 10 tahun. Paparan terorisme terhadap anak pun sudah sedemikian membekas, hingga pemulangannya juga akan membawa resiko. Namun asumsi tidak boleh dijadikan dasar untuk menelantarkan eks ISIS. Hal ini karena peran negara dalam menjaga kedamaian dunia, dapat diwujudkan dengan mengurusi warga negaranya yang melakukan kejahatan transnasional. Panti Sosial Marsudi Putra (PSMP) Handayani merupakan balai rehabilitasi bagi

\footnotetext{
13 Tomuschat. hal. $13-18$.

14 Elga Andina, 'Wacana Pemulangan Anak-Anak Kombantan ISIS', Puslit Bkd, 12.4 (2020),
} 
eks teroris. Hal ini dapat dimanfaatkan dalam rangka melakukan treatment atas "de-terorisasi dan de atrocitisasi" sebagai ideologi menyimpang dari eks ISIS yang cenderung menyakiti orang lain ataupun melakukan tindakan yang membahayakan diri sendiri.

Pemulangan warga negara Indonesia Eks ISIS, atau pemulangan Eks Warga negara yang bersumpah setia kepada ISIS, menemui pro dan kontra. Selanjutnya mengenai status kewarganegaraan Eks Anggota ISIS terdapat beberapa pandangan, yaitu: Pertama, Komnas HAM berpandangan bahwa pemerintah harus mampu mengambil keputusan yang tepat atas penanganan dan status kewarganegaraan WNI Eks ISIS dengan mempertimbangkan standar dan norma hak asasi manusia. ${ }^{15}$ Komnas HAM menitik beratkan pada hak asasi manusia terkait dengan status kewarganegaraan dari para pelaku kejahatan ISIS meskipun paham akan ada konsekuensi atas tindakan tersebut. Kedua, pemerintah berpandangan bahwa 689 WNI Eks ISIS yang berada di Suriah dan Turki merupakan teroris lintas batas atau FTF (foreign terrorist fighter) sehingga tidak akan memulangkan WNI Eks ISIS tersebut ke Indonesia. ${ }^{16}$ Namun demikian pemerintah masih mempertimbangkan memulangkan anak-anak WNI yang usianya di bawah 10 tahun dan telah gabung dengan ISIS. ${ }^{17}$ Hal ini telah menjadi kewajiban dari negara untuk menjamin hak asasi manusia setiap warga negara, termasuk hak asasi anak. ${ }^{18}$ Ketiga, salah satu korban selamat pada peristiwa pengeboman gereja di Surabaya pada bulan Mei 2018 yang dilakukan oleh ISIS berpandangan bahwa aksi dari ISIS sangat mengerikan dan membuat masyarakat tidak tenang, sehingga sangat mendukung keputusan pemerintah yang tidak akan mengembalikan WNI Eks ISIS yang saat ini tengah berada di Suriah ke negara Indoesia. ${ }^{19}$

Untuk mendapat pandangan terhadap kewarganegaraan sendiri, akan dikaji secara yuridis, bahwa terhadap dua isu utama yaitu kewarganegaraan sebagaimana diatur dalam Undang-Undang Nomor 12 Tahun 2006 tentang Kewarganegaraan Republik Indonesia, dan pemenuhan negara sebagaimana diamanatkan dalam deklarasi Montevideo. Dari alasan yang digunakan oleh

15 Ahmad Taufan Damanik, "Menimbang Kombatan ISIS Pulang", 2020, https://www.komnasham.go.id/, diakses 12 Februari 2021.

16 Andhika Prasetia, "Tok! Pemerintah Tak Akan Pulangkan WNI Eks ISIS", 2020, https://news.detik.com/berita/d-4894943/tok-pemerintah-tak-akan-pulangkan-wni-eks-isis.

17 Putu Merta Surya Putra, "Pemerintah Tak Pulangkan 689 WNI Anggota ISIS, Bagaimana Menangkal Penyusupan", 2020, https://www.liputan6.com/news/read/4177099/headline-pemerintahtak-pulangkan-689-wni-anggota-isis-bagaimana-menangkal-penyusupan.

18 Mohamad Rapik and Bunga Permatasari, "Penanganan Anak ISIS Dalam Perspektif Hukum Indonesia", Undang: Jurnal Hukum, 3.2 (2020), hal. 289-314, https://doi.org/10.22437/ujh.3.2.289314.

19 Reni Mardika, "Kontroversi Pemulangan WNI Eks ISIS, Ponto: Indonesia Harus Tidak Menerima", 2020, https://www.kompas.tv/article/65843. 
pemerintah terkait penolakan terhadap warga negara eks ISIS, ada beberapa ketentuan dalam Pasal 23 Undang-Undang Nomor 12 Tahun 2006 tentang Kewarganegaraan Republik Indonesia yang menjadi bahan pertimbangan. Jika dikaji lebih dalam pernyataan dari pemerintah terkait dengan pencabutan hak kewarganegaraan dikarenakan warga ISIS eks Indonesia telah membakar paspornya atau telah diatas lima tahun meninggalkan indonesia atau juga ada yang mengatakan bahwa turut serta dalam dinas negara lain. Perlu ditegaskan bahwa berdasarkan ketentuan Undang-Undang Nomor 12 Tahun 2006 tentang Kewarganegaraan Republik Indonesia, Indonesia tidak mengenal pencabutan kewarganegaraan akan tetapi penghilangan kewarganegaraan. Jadi terkait kewarganegaraan ini karena Indonesia adalah negara hukum maka alasan-alasan tersebut tidak bisa digunakan. Dengan demikian status kewarganegaraan WNI sebagai pendukung ISIS tidak dapat dicabut kewarganegaraan. ${ }^{20}$.

Demografi dari penduduk ISIS menunjukkan jumlah orang yang kemungkinan akan menjadi stateless ketika negara-negara asal (afiliasi) melakukan pencabutan kewarganegaraan. Dengan kondisi stateless, maka kemungkinan penyebaran dan pencegahan faham ini akan sangat berbahaya. Oleh karena itu peran aktif pemerintah diperlukan untuk mencegah hal tersebut terjadi. Aturan yang dapat digunakan menangkal kembalinya warga negara Indonesia eks ISIS adalah Pasal 236 ayat (2) huruf a Peraturan Pemerintah Nomor 31 Tahun 2013 tentang Peraturan Pelaksanaan UndangUndang Keimigrasian disebutkan bahwa orang yang terlibat kejahatan transnasional terorganisasi, bisa ditangkal masuk ke Indonesia. Namun bukan pilihan yang bijak untuk menangkal WNI eks ISIS meskipun dimungkinkan untuk melakukan hal tersebut. Membiarkan warga negaranya (eks ISIS) untuk berkeliaran dan di deportasi (kemana) bukanlah pilihan yang bijak, pilihan politik bisa menunjukkan tanggung jawab negara atas warga negaranya yang melakukan kejahatan.

Berdasarkan UU kewarganegaraan dan dikaitkan dengan deklarasi Montevideo, maka Indonesia secara diam-diam mengakui kedaulatan dari ISIS dengan mengatakan "menolak Eks WNI yang terlibat ISIS karena telah bergabung ke Negara lain, baik sumpah setia ataupun bergabung dalam tentara perang negara lain”. Kata yang perlu digaris bawahi adalah "negara" bahwa menggunakan UU Kewarganegaraan menolak Eks ISIS adalah pengakuan secara diam-diam. Indonesia perlu bertanggung jawab terhadap internasional terkait warganya yang melakukan kejahatan. Bukan

20 Gusti Ngurah, Surya Adhi, and Kencana Putra, "Status Kewarganegaraan Indonesia Bagi Pendukung Isis (Islamic State of Iraq and Syria)", Journal Ilmu Hukum Kertha Negara, 4.5 (2016), hal.6. 
membiarkannya terus melakukan kejahatan dan potensial untuk kembali ke Indonesia dan menyebarkan permasalahan baru, sehingga konsep dari pengembalian WNI eks ISIS adalah memberikan treatment yang tepat untuk menjaga keamanan dunia pada umumnya dan keamanan Indonesia pada khususnya.

Pilihan politik antara melindungi antara HAM pelaku kejahatan (ISIS) dengan HAM penduduk Indonesia yang berjumlah 267 juta jiwa, khususnya bagi korban-korban kejahatan ISIS di Indonesia merupakan hal yang dilematis. Pertentangan ini dimunculkan dalam pernyataan pemerintahan Indonesia ketika menimbang apakah akan memulangkan eks penduduk Indonesia yang memilih untuk pergi ke Irak atau Suriah ataupun ke negara lain dengan tujuan untuk membantu ISIS. Perlindungan HAM di Indonesia diatur dalam konstitusi, sebagai konsekuensi logis sebuah negara hukum. Hal ini mengandung pengertian bahwa sebagai negara hukum Indonesia melindungi hak asasi warga negara.

Terorisme memiliki dampak langsung pada penikmatan hak asasi manusia. Dengan demikian, negara memiliki kewajiban untuk mengambil langkah-langkah kontra terorisme yang efektif. Sebagaimana perumusan HAM generasi ke 2 (right to), maka untuk menjamin freedom from fear pemerintah dituntut menyediakan perlindungan terhadap hak ekonomi, sosial dan budaya, hal ini menuntut peran aktif pemerintah. ${ }^{21}$ Masyarakat Indonesia mempunyai hak atas negara yang aman dalam bentuk peran aktif negara. Kewajiban untuk memastikan bahwa semua tindakan anti-terorisme dilakukan sendiri mematuhi standar hak asasi manusia dan fleksibilitas yang dibangun di dalamnya hukum hak asasi manusia untuk menangani keadaan luar biasa merupakan fungsi negara dalam penanganan terorisme. Right to dikemas dalam bahasa positif sebagai konsekuensi dari kewajiban pemerintah untuk menyediakan hal tersebut.

Pasal 30 dan Pasal 35 Undang-Undang Republik Indonesia Nomor 39 Tahun 1999 tentang Hak Asasi Manusia mengisyaratkan adanya peran aktif dari pemerintah. Begitupun dengan perspektif HAM dari pelaku kejahatan (ISIS) bahwa jaminan atas kesamaan di depan hukum bagi ISIS juga harus ditegakkan. Pemerintah dalam hal ini mempunyai kewajiban atas dilematis melindungi warga negaranya dari rasa takut, namun juga berkewajiban menegakkan hukum (jaminan persamaan di depan hukum) bagi warga negaranya yang melanggar hukum. Dengan makna proporsionalitas atas hukuman yang mereka dapat sesuai dengan peran mereka dalam kejahatan

21 Satya Arinanto, Hak Asasi Manusia Dalam Transisi Politik Di Indonesia, Cetakan ke (Jakarta: Pusat Studi Hukum Tata Negara Fakultas Hukum Universitas Indonesia, 2018), hal.79. 
selama menjadi bagian dari ISIS. Hal yang bisa dituntutkan karena perumusan HAM generasi kedua menggunakan right to, yang mengindikasikan harus ada tindakan afirmatif dari pemerintah.

Ketertiban masyarakat dan perlindungan atas rasa takut, dihadapkan pada hak kesamaan dimuka hukum bagi pelaku kejahatan ISIS, oleh karena itu peran aktif negara sangat diperlukan. Bentuk dari melaksanakan ketertiban dunia dapat ditunjukkan dengan menindak penduduk Indonesia yang melakukan kejahatan. Pemerintah dituntut untuk aktif dan bertanggung jawab terhadap rakyatnya. Hal tersebut merupakan bentuk perlindungan terhadap Indonesia juga. Pemaksimalan dari fungsi lembagalembaga pemerintah dan non pemerintah Indonesia merupakan bentuk politik bebas aktif dalam rangka melaksanakan ketertiban dunia, dan sebagaimana HAM generasi kedua menuntut peran aktif dari pemerintah. ${ }^{22}$

Proses pencabutan kewarganegaran dan pencekalan ataupun pemidanaan atas pelanggaran dan kejahatan yang dilakukan eks ISIS asal Indonesia harus dilakukan dengan memulangkan mereka sebagai bentuk tanggung jawab negara. Mereka pulang untuk disidangkan oleh Indonesia sesuai kejahatan yang mereka lakukan. Sebagaimana prinsip-prinsip hukum humaniter internasional yang diatur dalam $151 \mathrm{KBI} / \mathrm{KBNI}$ bahwa pertanggung jawaban kejahatan perang yang dilakukan ISIS masuk ke dalam pertanggung jawaban pribadi. ${ }^{23}$ Eks ISIS asal Indonesia harus bertanggung jawab atas kejahatan yang mereka lakukan semasa menjadi anggota ISIS. Eks ISIS melanggar hukum hak asasi manusia internasional dengan melakukan penyerangan tanpa ada prinsip pembedaan antara penduduk sipil dan militer (kombatan) dan telah mengeksploitasi anak-anak, perempuan dapat diadili oleh pengadilan nasional sepanjang negara dianggap "mampu dan berkeinginan" untuk mengadilinya. ${ }^{24}$

Pertimbangan antara HAM dari pelaku kejahatan dan perlindungan terhadap keamanan warga negara terlihat dalam ketentuan International Covenant on Civil and Political Rights (ICCPR), "Setiap orang mempunyai kedudukan yang sama dalam hukum. Asas ini disebut juga equality before the law yang disebut dalam Pasal 7 Universal Declaration of Human Rights (UDHR), Pasal 26 International Covenant on Civil and Political Rights hal. 16 .

${ }^{22}$ Rhona K. M. Smith, et.al. Hukum Hak Asasi Manusia (Yogyakarta: Pusham UII, 2008),

23 Jean-Marie Henckaerts, 'Kebiasaan: Sebuah Sumbangan Bagi Pemahaman Dan Penghormatan Terhadap Tertib Hukum Dalam Konflik Bersenjata', Internasional Review of the Red Cross, 87.857 (2005), hal. 43.

${ }^{24}$ Ayub Torry Satriyo Kusumo and Kukuh Tejomurtia, "Alternatif Atas Pemberlakuan Hukum Humaniter Internasional Dalam Konflik Bersenjata Melawan', Jus Ad Bellum, Jus in Bello, 4.3 (2015), hal. 639-640. 
(ICCPR), Pasal 27 ayat (1), Pasal 28D Undang-Undang Dasar 1945". ${ }^{25}$ Sebagai hak non derogable, maka tanggung jawab pemerintah sebagai perwujudan HAM generasi ke 2 (right to) sama halnya dengan hak perlindungan terhadap keamanan warga negaranya. Jadi baik hak eks ISIS ataupun hak warga negara bukanlah suatu dikotomis, namun merupakan kewajiban pemerintah untuk memenuhinya sebagai hak yang non derogable, sesuai sifat HAM yang inherent, dan inalienable sehingga tidak ada alasan untuk hanya memilih salah satu, semuanya harus dilakukan.

Sehingga dapat ditarik kesimpulan atas perspective HAM jika dikaitkan antara dilema perlindungan HAM warga negara dengan HAM dari WNI eks ISIS bukanlah pilihan, namun suatu tanggung jawab yang harus dilakukan oleh negara. Tanggung jawab ini merupakan bentuk politik bebas aktif dari negara. Kemungkinan fenomena ISIS ini untuk berlanjut kelihatannya sangat potensial. Sehingga jika negara tidak hadir dalam menyelesaikan masalah ini dan menolak warga negara Indonesia eks ISIS hanya akan menjadi bom waktu bagi Indonesia. Oleh karena itu penanganan warga eks ISIS ini sebagai cara me-manage permasalahan terorisme di Indonesia. Pendekatan kemanusiaan atas WNI eks ISIS dapat menjadi obat yang diambil dari "vaksin mantan ISIS" yang terpapar terorisme, dan sudah sembuh untuk menyembuhkan penyakit terorisme yang akan datang.

\section{PENUTUP}

Kedudukan ISIS dalam konstelasi Internasional bukan negara akan tetapi organisasi massa pelaku kejahatan (mass crime) karena tidak memenuhi syarat negara sebagaimana tertuang dalam deklarasi Montevideo. Dari sisi pelanggaran HAM, ISIS merupakan pelanggar HAM berat, dan dapat dikategorikan sebagai penjahat perang sebagaimana hukum humaniter internasional. Dilema dalam WNI eks ISIS ke Negara Indonesia meliputi 5 hal, yaitu: 1) Dari sisi kewarganegaraan Indonesia tidak mengenal pencabutan, namun memungkinkan dilakukan penangkalan berdasarkan pada Peraturan Pemerintah Nomor 31 Tahun 2013 tentang Peraturan Pelaksanaan UU Keimigrasian; 2) Klaim atas kehilangan Kewarganegaraan karena ikut berperang pasukan negara asing, ataupun syarat-sarat dalam Undang-Undang Kewarganegaraan lainnya akan berimplikasi pengakuan kedaulatan ISIS; 3) Pilihan politik antara perlindungan terhadap ketertiban masyarakat ataupun perlindungan HAM pelaku (ISIS) dapat dipandang secara komplementer (tidak dikotomis), dengan memulangkan WNI eks ISIS dapat menjadi kontrol dan iktikad baik pemerintah karena pemulangannya untuk disidangkan sesuai porsi kejahatannya, dan dalam rangka melindungi warga

25 Rhona K. M. Smith, et.al.,hal. 259. 
negara Indonesia; 4) Hak perlindungan dalam bentuk freedom from fear harus di affirmasi melalui tindakan pemerintah sebagai bentuk perkembangan generasi ke dua HAM (right to) hak untuk mendapatkan perlindungan dan perlakuan yang sama di dalam hukum; dan 5) Langkah pemulangan Eks ISIS adalah bentuk politik luar negeri bebas dan aktif Indonesia dalam menjaga ketertiban dunia dengan menindak warga negaranya yang melakukan kejahatan transnasional. Pemerintah dapat mengambil kebijakan untuk memulangkan warga ISIS yang berasal dari Indonesia dan mengadilinya sebagaimana porsi kejahatan mereka dan perannya dalam ISIS, selain itu pemerintah juga harus merumuskan treatment yang tepat bagi WNI eks ISIS melalui strategi pemetaan WNI eks ISIS berdasarkan umur, intensi bergabung, kejatahan yang dilakukan serta pemetaan menyeluruh WNI Eks ISIS.

\section{DAFTAR PUSTAKA}

Andina, Elga, 'Wacana Pemulangan Anak-Anak Kombantan ISIS', Puslit Bkd, 12.4 (2020), 13-18.

Arif Sumawiharja, Farhan, and Adis Imam Ismunandar, 'Analisa Kebijakan Penerimaan WNI Mantan Simpatisan ISIS Di Suriah (Policy Analysis of Re-Acceptance Indonesia Citizenship Former ISIS in Suriah)', Jurnal Keamanan Nasional, VI.1 (2020), 107 <https://elshinta.com/news/160416/2018/11/08/menhan-sebut-700wni-gabung-isis-di-suriah-dan-.

Arinanto, Satya, Hak Asasi Manusia Dalam Transisi Politik Di Indonesia, Cetakan ke (Jakarta: Pusat Studi Hukum Tata Negara Fakultas Hukum Universitas Indonesia, 2018).

Ayub Torry Satriyo Kusumo, and Kukuh Tejomurtia, 'Alternatif Atas Pemberlakuan Hukum Humaniter Internasional Dalam Konflik Bersenjata Melawan', Jus Ad Bellum, Jus in Bello, 4.3 (2015), 639-64.

Damanik, Ahmad Taufan, "Menimbang Kombatan ISIS Pulang', 2020, https://www.komnasham.go.id/, diakses 12 Februari 2021.

DH, Agung, 'Kesaksian Penumpang Bus Trans Jakarta Saat Bom Meledak', 2017, https://tirto.id/cpnc https://tirto.id/cpnc, - 25 Mei 2017, diakses 21 Februari 2021.

EPA, 'Polri: Korban Ledakan Di Sarinah 7 Tewas, 5 Adalah Pelaku', 2016, https://www.bbc.com/indonesia/berita_indonesia/2016/01/160114_ind onesia_jumlah_korban.

Hakim, Abdurrahman, and Iffatin Nur, 'Indonesia Eks ISIS', 9.1 (2020), 8198.

Henckaerts, Jean-Marie, 'Kebiasaan: Sebuah Sumbangan Bagi Pemahaman Dan Penghormatan Terhadap Tertib Hukum Dalam Konflik Bersenjata', Internasional Review of the Red Cross, 87.857 (2005), 43.

Lovelycia, Keivelyn, 'Indonesia Atas Kepulangan Warga Negara Indonesia Eks Isis (Islamic State Of Iraq And Syria) Ditinjau Dari Hukum Positif 
Indonesia', Jurnal Hukum Adigama, 3.2 (2020), 1213-38.

Mardika, Reni, 'Kontroversi Pemulangan WNI Eks ISIS, Ponto: Indonesia Harus Tidak Menerima', 2020, https://www.kompas.tv/article/65843.

Neriah, J, 'The Structure of the Islamic State ISIS', Jerusalem Center for Public Affairs, 2014, https://jcpa.org/structure-of-the-islamic-state/.

Ngurah, Gusti, Surya Adhi, and Kencana Putra, 'Status Kewarganegaraan Indonesia Bagi Pendukung Isis (Islamic State of Iraq and Syria)', Kertha Negara : Journal Ilmu Hukum, 4.5 (2016), 1-6.

Prasetia, Andhika, 'Tok! Pemerintah Tak Akan Pulangkan WNI Eks ISIS', 2020, https://news.detik.com/berita/d-4894943/tok-pemerintah-takakan-pulangkan-wni-eks-isis.

Putu Merta Surya Putra, 'Pemerintah Tak Pulangkan 689 WNI Anggota ISIS, Bagaimana Menangkal Penyusupan', 2020, https://www.liputan6.com/news/read/4177099/headline-pemerintahtak-pulangkan-689-wni-anggota-isis-bagaimana-menangkalpenyusupan.

Rapik, Mohamad, and Bunga Permatasari, 'Penanganan Anak ISIS Dalam Perspektif Hukum Indonesia', Undang: Jurnal Hukum, 3.2 (2020), 289-314, https://doi.org/10.22437/ujh.3.2.289-314.

Rhona K. M. Smith, et.al., Hukum Hak Asasi Manusia (Yogyakarta: Pusham UII, 2008).

Shamieh, Luna, and Szenes Zoltán, 'The Rise of Islamic State of Iraq and Syria (ISIS) Islam and Politics', Aarms, 14.4 (2015), 363-78.

Soerjono Soekanto, Sri Mamuji, Penelitian Hukum Normatif (Jakarta: Raja Grafindo Persada, 2004)

'The Islamic State: How Its Leadership Is Organized', 2014, https://www.youtube.com/watch?v=1HzMucorCwo.

Tomuschat, Christian, "The Status of the "Islamic State" under International Law', Die Friedens-Warte, $90 \quad$ (2015), 229 , https://www.jstor.org/journal/friedenswarte?. 